\title{
Processes and causes of Phanerozoic tectonic evolution of the western Tarim Basin, northwest China
}

\author{
Teng-Fei Wang ${ }^{1,2,3} \cdot$ Zhen-Kui Jin $^{2} \cdot \mathrm{He} \mathrm{Li}^{4} \cdot$ Dong-Qing Liu ${ }^{5} \cdot \mathrm{Ri}^{-H u i}$ Cheng ${ }^{3} \cdot$ Shu-Ting Shi ${ }^{2} \cdot$ Jin-Yi Wang $^{2}$
}

Received: 10 August 2018 / Published online: 6 February 2020

(c) The Author(s) 2020

\begin{abstract}
This paper addresses the Phanerozoic tectonic evolution of the western Tarim Basin based on an integrated stratigraphic, structural and tectonic analysis. P-wave velocity data show that the basin has a stable and rigid basement. The western Tarim Basin experienced a complex tectonic evolutionary history, and this evolution can be divided into six stages: Neoproterozoic to Early Ordovician, Middle Ordovician to Middle Devonian, Late Devonian to Permian, Triassic, Jurassic to Cretaceous and Paleogene to Quaternary. The western Tarim Basin was a rift basin in the Neoproterozoic to Early Ordovician. From the Middle Ordovician to Middle Devonian, the basin consisted of a flexural depression in the south and a depression that changed from a rift depression to a flexural depression in the north during each period, i.e., the Middle-Late Ordovician and the Silurian to Middle Devonian. During the Late Devonian to Permian, the basin was a depression basin early and then changed into a flexural basin late in each period, i.e., the Late Devonian to Carboniferous and the Permian. In the Triassic, the basin was a foreland basin, and from the Jurassic to Cretaceous, it was a downwarped basin. After the Paleogene, the basin became a rejuvenated foreland basin. Based on two cross sections, we conclude that the extension and shortening in the profile reflect the tectonic evolution of the Tarim Basin. The Tarim Basin has become a composite and superimposed sedimentary basin because of its long-term and complicated tectonic evolutionary history, highly rigid and stable basement and large size.
\end{abstract}

Keywords Western Tarim Basin · Phanerozoic · Structural evolution · Composite and superimposed sedimentary basin

\section{Introduction}

The Eurasia-India collision shaped the present topography of northwest China (Lu et al. 1994; Kao et al. 2001; Jiang et al. 2017). The Tarim Basin is located where intense regional compression has dominated since the Cenozoic

Edited by Jie Hao

Zhen-Kui Jin

jin.zk@hotmail.com

$1 \quad$ Faculty of Land Resources Engineering, Kunming University of Science and Technology, Kunming 650093, China

2 College of Geosciences, China University of Petroleum (Beijing), Beijing 102249, China

3 College of Earth Sciences, Jilin University, Changchun 130061, Jilin, China

4 Geological Research Center, Bureau of Geophysical Prospecting, Zhuozhou 072751, Hebei, China

5 Shenzhen Branch of CNOOC China Limited, Shenzhen 518000, Guangdong, China
(Molnar and Tapponnier 1977; Sobel and Dumitru 1997) (Fig. 1). The basin has a complicated tectonic evolutionary history and is classified as a composite and superimposed sedimentary basin (Jia 2003). Studying the evolution of the Tarim Basin can be useful to understand the relationship between the tectonic background and basin evolution.

Some efforts have been made to reconstruct the tectonic and stratigraphic evolution of the western Tarim Basin (Jin et al. 2003; Qu et al. 2005; Heermance et al. 2007; Wei et al. 2013), but few investigations have incorporated processes throughout the entire Phanerozoic Eon. This paper attempts to reconstruct the tectonic evolutionary history of the western Tarim Basin and to determine its basement characteristics to understand how it evolved into a composite and superimposed sedimentary basin.

\section{Geological setting}

The Tarim Basin, which has an area of approximately $560,000 \mathrm{~km}^{2}$, is located in the southern Xinjiang Uygur Autonomous Region, northwest China. 


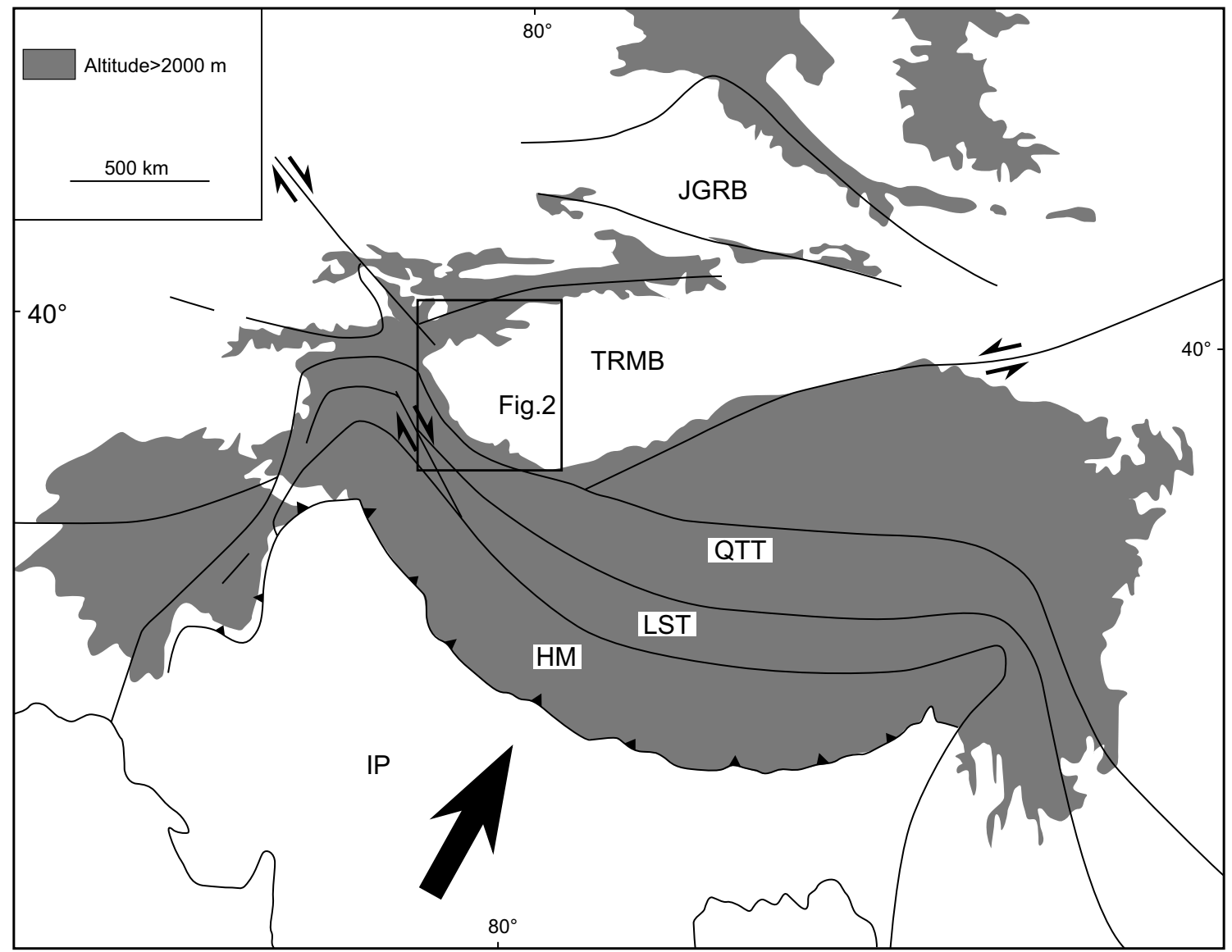

Fig. 1 Schematic map showing the tectonic setting of the western Tarim Basin (modified from Sobel and Dumitru 1997). TRMB = Tarim Basin; JGRB = Junggar Basin; QTT = Qiangtang Terrane; LST = Lhasa Terrane; HM = Himalaya; and IP = India Plate

The western part of the Tarim Basin is surrounded by the Tianshan Mountains to the northwest, the Pamir Plateau to the west and the West Kunlun Mountains to the southwest (Fig. 2). Intense regional compression, originating from the northward movement of the Indian Plate, has been concentrated in this area since the Cenozoic (Molnar and Tapponnier 1977; Sobel and Dumitru 1997; Zhang et al. 2002; Ji et al. 2008).

Generally, the Tarim Basin has Neoproterozoic to Paleozoic marine sedimentary cover and Mesozoic to Quaternary nonmarine sedimentary cover, where the Permian was a transitional period between the marine and continental facies (Jia et al. 2004). However, in the western Tarim Basin, marine deposits also occurred after the Permian (Wei et al. 2013). Figure 3 shows the general stratigraphic sequence of the western Tarim Basin. Glacial gravels, dolostone and subaerial clastic rocks characterize the Neoproterozoic deposits in the western Tarim Basin. Dolostone, limestone and gypsum-bearing rocks occur in the Cambrian strata. The Ordovician deposits are composed of limestone, dolostone, argillaceous sandstone and siltstone. The Silurian deposits are shale in the lower units and sandstone and siltstone in the upper units. The Devonian deposits are composed of siltstone and sandstone. Limestone, gypsum-bearing rocks and mudstone characterize the Carboniferous deposits. The Permian deposits are limestone, sandy mudstone, mudstone and basic volcanic rocks. Conglomerate, sandstone, siltstone and mudstone characterize the Triassic deposits. The Jurassic strata are composed of conglomerate, sandstone and siltstone in the lower units, mudstone and shales in the middle units and conglomerate in the upper units. The Cretaceous strata consist of sandstone, conglomerate, gypsum-bearing rocks, mudstone and shale. The Paleogene strata are composed of limestone and gypsum-bearing rocks in the Paleocene, mudstone and limestone in the Eocene and mudstone in the Oligocene. Mudstone, sandstone and conglomerate occur in the Neogene strata. In addition, the Quaternary strata are composed of conglomerate, sandstone and argillaceous siltstone.

Sutures on the northern, western and southern edges of the Tarim Basin record the plate amalgamation history of 


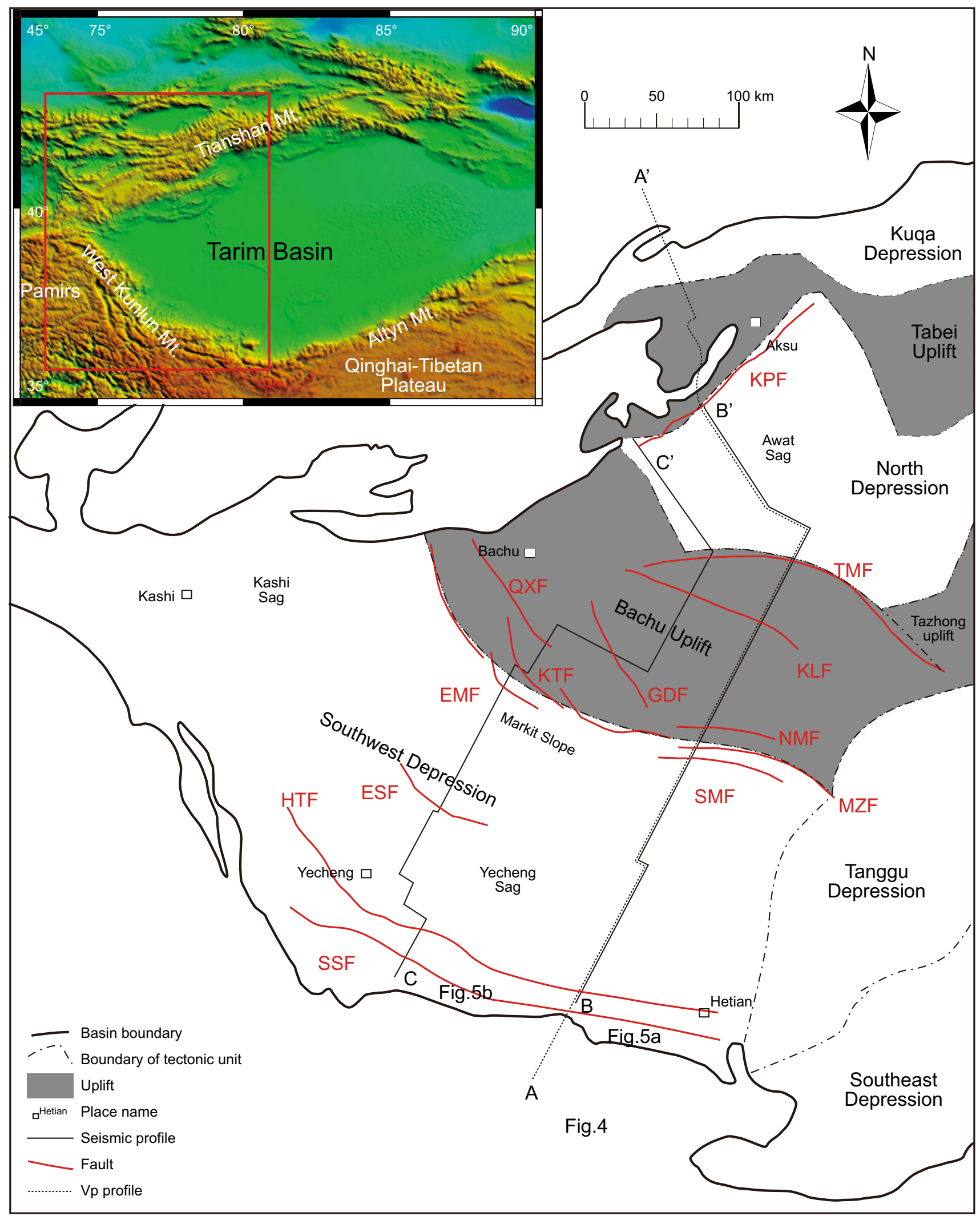

Fig. 2 Topographic map and tectonic unit divisions of the western Tarim Basin 


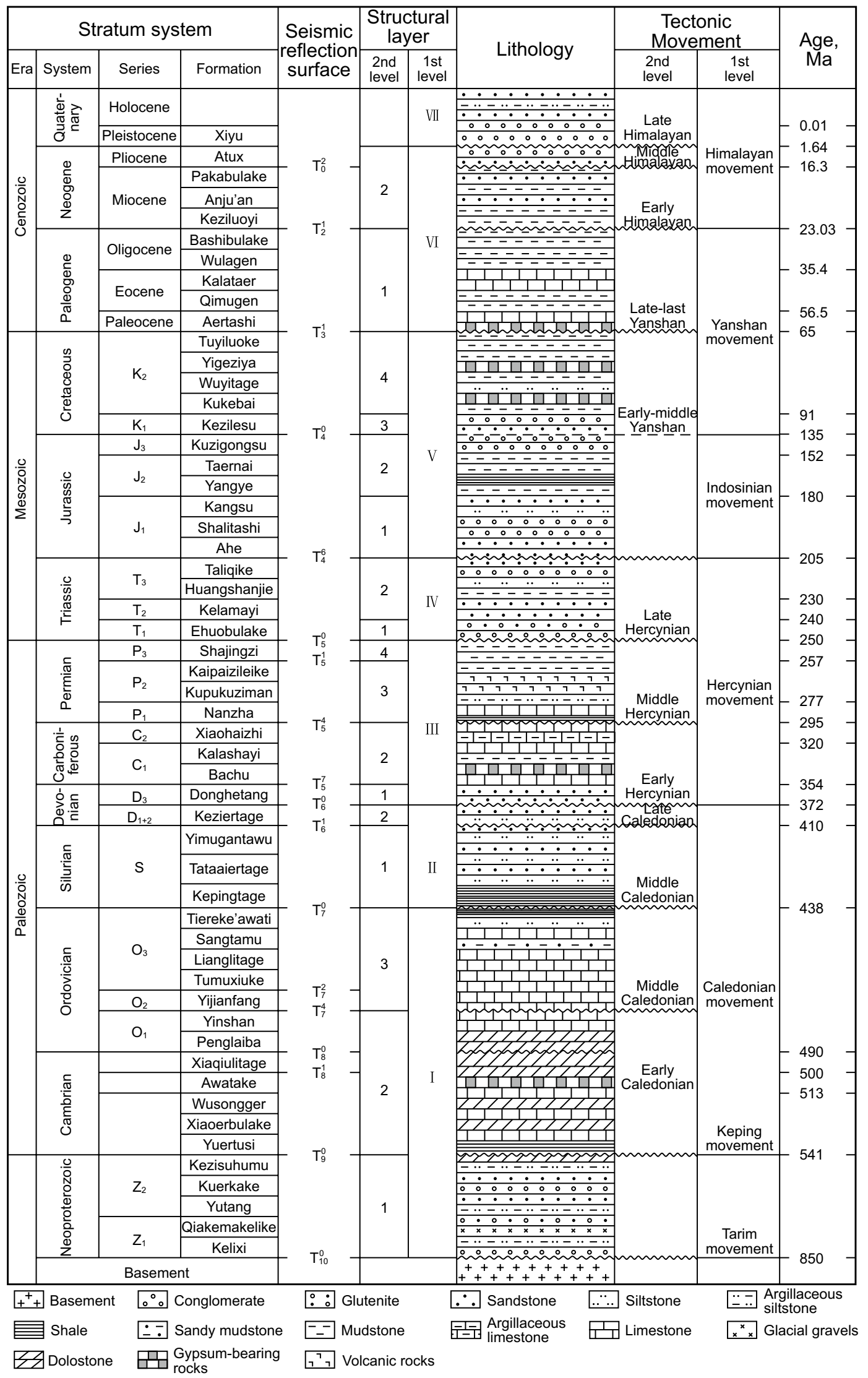

Fig. 3 Stratigraphic and lithological sequences of the western Tarim Basin (modified from Lin et al. 2012) 
the Tarim Block. The Tarim Block amalgamated with the Yili-Central Tianshan Terrane in the Carboniferous (Gao et al. 2009; Su et al. 2010; Ge et al. 2012; Liu et al. 2014; Ma et al. 2014; Zhang et al. 2014) and with the Qiangtang Terrane in the Triassic (Xiao et al. 2003; Liu et al. 2013; Pullen et al. 2015; Xu et al. 2015).

\section{Basement characteristics}

The western Tarim Basin has a Precambrian crystalline basement (Tian et al. 1989; Jia 2003; Guo et al. 2005; Li et al. 2005; Xu et al. 2013). In this paper, P-wave velocity data show the characteristics of the basement.

\subsection{Data}

Earthquake events that were detected by at least three stations and have more than six seismic phases within $74-90^{\circ}$ E longitude and $35-42^{\circ} \mathrm{N}$ latitude are chosen. By using the tomography method (Cutler et al. 1984; Zhao 2009; Tromp et al. 2010), more than 14,000 $\mathrm{P}$-wave records are determined to obtain a three-dimensional P-wave velocity (Vp) structure.

Twenty-nine Vp profiles are imaged throughout the entire Tarim Basin with a depth of $100 \mathrm{~km}$ and a total length of $52,592 \mathrm{~km}$. In this paper, profile A-A' is shown (Fig. 4).

\subsection{Interpretation}

The profile is ca. $664 \mathrm{~km}$ long and extends generally from south to north. The Moho surface is uplifted between the distances of $100 \mathrm{~km}$ and $600 \mathrm{~km}$ within the basin. At the top of the upper mantle near the Moho interface, the velocity distribution changes frequently, and the contours show complicated forms.

The upper crust and lower crust are separated by a velocity contour of $6.60 \mathrm{~km} / \mathrm{s}$. The lower crust is clearly thicker than the upper crust, suggesting that the Tarim Basin has a highly rigid and stable crust because it is composed of highdensity, rigid, evenly distributed materials.

In addition, a high-velocity belt appears in the lower crust at depths of $15-25 \mathrm{~km}$ and between distances of $25 \mathrm{~km}$ and $625 \mathrm{~km}$ and encompasses almost the entire basin. The thickness of the high-velocity belt is ca. $8 \mathrm{~km}$ and decreases to ca. $2 \mathrm{~km}$ to the south and north. In the lower crust, the velocity distribution is even.

\section{Tectonic evolution}

\subsection{Method of balanced cross-sectional restoration}

The restoration of a balanced cross section refers to the stepby-step restoration of an interpreted structural cross section to its pre-deformed morphology. The stratum length balance restoration method and the area balance restoration method are used in this study.

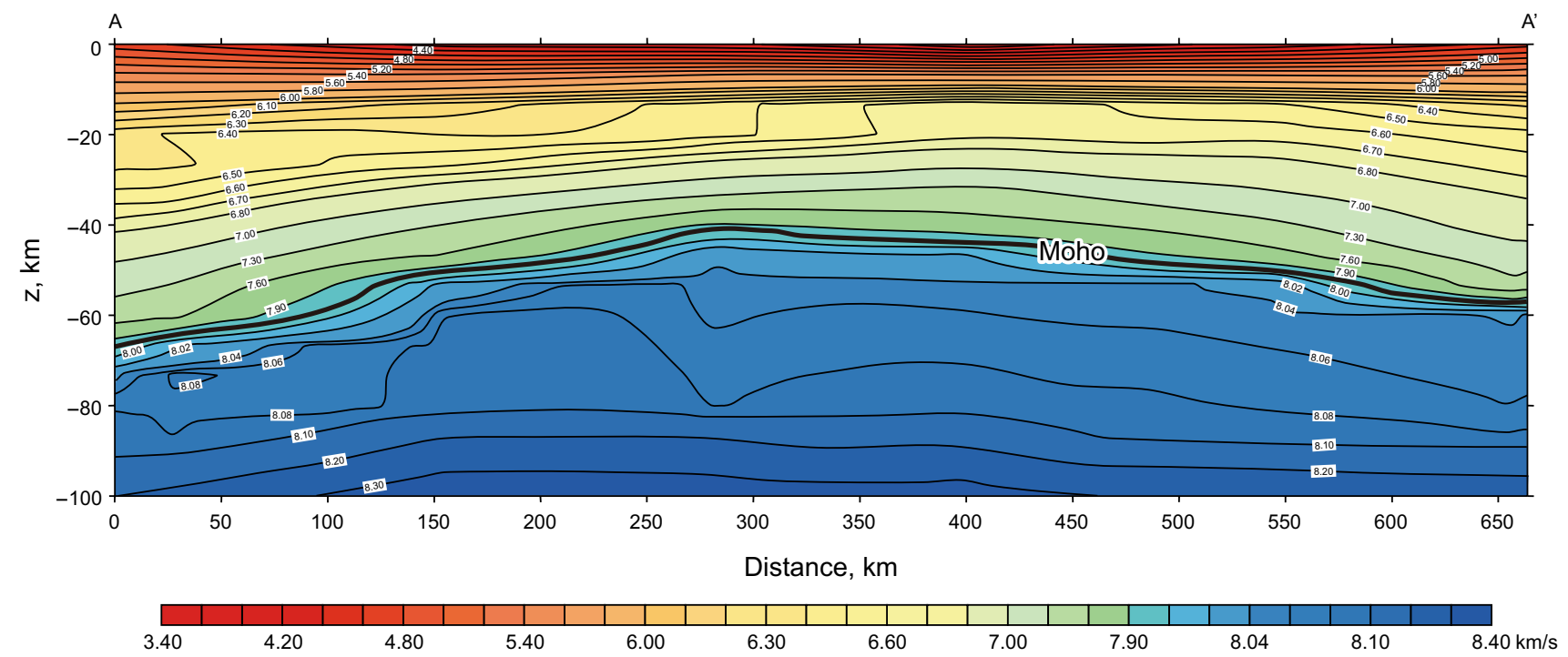

Fig. 4 P-wave velocity distribution along the profile A-A'. The location is shown in Fig. 2 
In this study, the area balance restoration method (Jiang et al. 2017) is used to recover the balanced cross section, and hand drawing on calculating papers is performed during the whole process. The interpreted seismic profile is transferred from time to depth first, and every detail about the evolution of each fault and strata deformation is planned. Then, the process involves the step-by-step restoration from the Neoproterozoic to the Quaternary, i.e., forward modeling. Compaction and denudation are restored in each stage. Finally, the drawings are converted into computer graphics by a scanner and the software Corel Draw (version 2018).

\subsection{Tectonic evolution}

The Tarim Basin experienced a long tectonic evolutionary history. Two seismic profiles are selected to recover the tectonic evolution by the method of balanced cross-sectional restoration. Both profiles are oriented nearly N-S and extend across the Southwest Depression, Bachu Uplift and North Depression (Figs. 2, 5), which have similar evolutionary histories. TLM-Z15 (B-B') is approximately $411 \mathrm{~km}$ long, and TLM-Z10 $\left(\mathrm{C}-\mathrm{C}^{\prime}\right)$ is approximately $408 \mathrm{~km}$ long.

In the Neoproterozoic, the Tarim Basin began to subside and accumulate sediment, and the western basin was in an extensional environment (Fig. 6k). The Tumuxiuke Fault, a normal fault, controlled the basin and was active during the depositional process, resulting in thickness differences in the sedimentary cover between the footwall and hanging wall. During the Early and Middle Cambrian and during the Late Cambrian to Early Ordovician, the western basin inherited a previous tectono-sedimentary framework and was still controlled by the Tumuxiuke Fault (Fig. 6i, j).

In the Middle and Late Ordovician, the southern section of the profile, as a part of the southwestern Tarim-Altyn Uplift (Jia 2003), underwent denudation because of the southward subduction of the West Kunlun Paleo-Ocean (He et al. 2007; He et al. 2015). The northern part of the western basin was extensional, subsided and accumulated sediment (Fig. 6h). The Tumuxiuke Fault continued to act as a normal fault. During the Late Ordovician, intense compression uplifted the entire western basin and caused denudation. The Tumuxiuke Fault was inverted, changing its dip direction, and the South Mazhatage Fault was formed. During the Silurian to Middle Devonian, the southern part of the western basin was still uplifted and underwent denudation that resulted from the closure of the Proto-Tethys Ocean (Xu et al. 2011; Li et al. 2017; Zhang et al. 2017a). The northern part of the western basin remained extensional, subsided and accumulated sediment (Fig. 6g). At the end of this stage, the entire region was uplifted and underwent denudation, and the Tumuxiuke Fault acted as a reverse fault.

During the Late Devonian to Carboniferous, the profile records weakly extensional conditions, and the basin subsided and accumulated sediment (Fig. 6f). At the end of this stage, the entire region was uplifted and underwent denudation. Moreover, the Tumuxiuke Fault was inverted, which thinned the total thickness of the strata on the hanging wall. During the Permian, the evolutionary process of the basin was similar to that during the previous stage (Fig. 6e). In the Early Permian, the western basin had an extensional environment and subsided rapidly. The western basin accumulated thick depositional cover during this period, and the South Mazhatage Fault was not active. In the Late Permian, the regional background turned compressional. Intense fold deformation occurred in the middle part of the profile, forming the Bachu Uplift structural prototype. The Tumuxiuke Fault acted as a reverse fault and caused rapid denudation of the deposits on the hanging wall.

In the Triassic, the basin was under compressional conditions because of the subduction of the Paleo-Tethys Ocean (Liu et al. 2013; Metcalfe 2013; Pullen et al. 2015; Xu et al. 2015). The northern part of the western basin was a compressional basin and accumulated deposits, while the southern part was uplifted and denuded (Fig. 6d).

In the TLM-Z15 profile, the Jurassic and Cretaceous strata are absent, which was caused by the closure of the Meso-Tethys Ocean and the collision between the Qiangtang and Lhasa terranes (Wang et al. 2012; Zhang et al. 2017b).

In the Paleogene, the northern and southern parts of the western basin accumulated deposits as compressional basins, and the Bachu Uplift in the middle part of the profile acted as the shared frontal uplift and was denuded (Fig. 6c). In the Miocene, the western basin inherited the previous tectono-sedimentary framework (Fig. 6b). Moreover, the regional compression was more intense because of the distant collision from the northward movement of the Indian Plate (Lu et al. 1994; Liu and Wang 1995; Mcquarrie et al. 2003; Wei et al. 2013). As an uplifted area of the basement, the Bachu Uplift still accumulated a small amount of deposits. In addition, the Mazhatage Fault, North Mazhatage Fault and Kalashayi Fault were activated. The Pliocene and Quaternary development of the western basin inherited the characteristics of the Miocene, and the present tectonic style was initiated.

The extensional ratio and length changes of TLM-Z15 shown in Table 1 highlight the influence of the regional stress field on the tectonic evolution. The western basin has undergone six stages, namely the Neoproterozoic to Early Ordovician, Middle-Late Ordovician to Early-Middle Devonian, Late Devonian to Permian, Triassic, Jurassic to Cretaceous and Paleogene to Quaternary. 


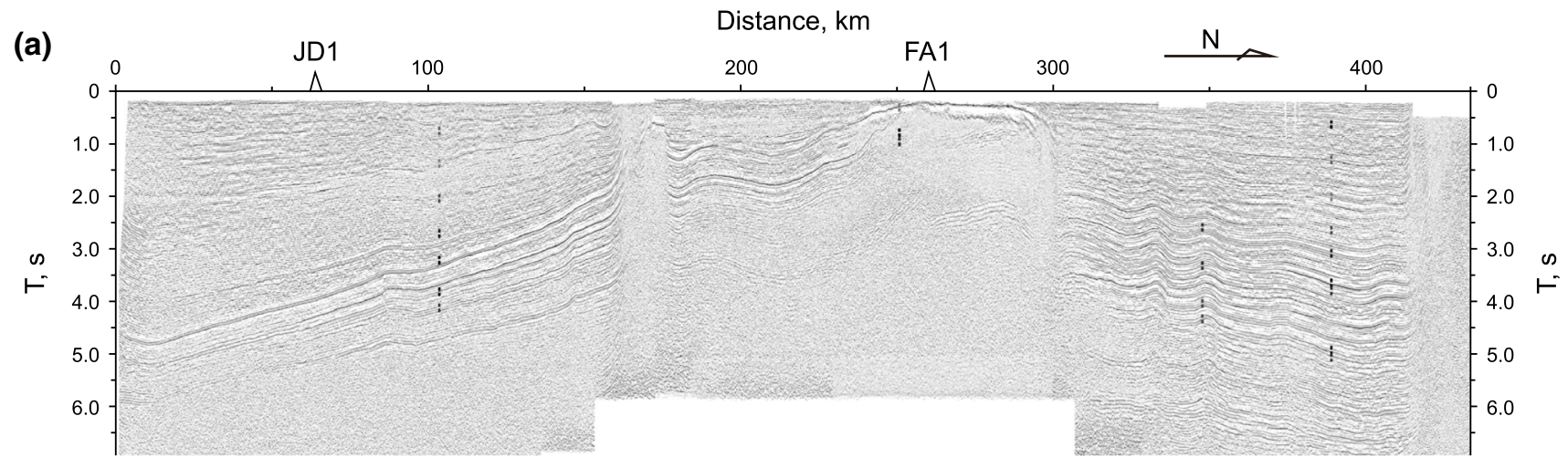

Distance, $\mathrm{km}$
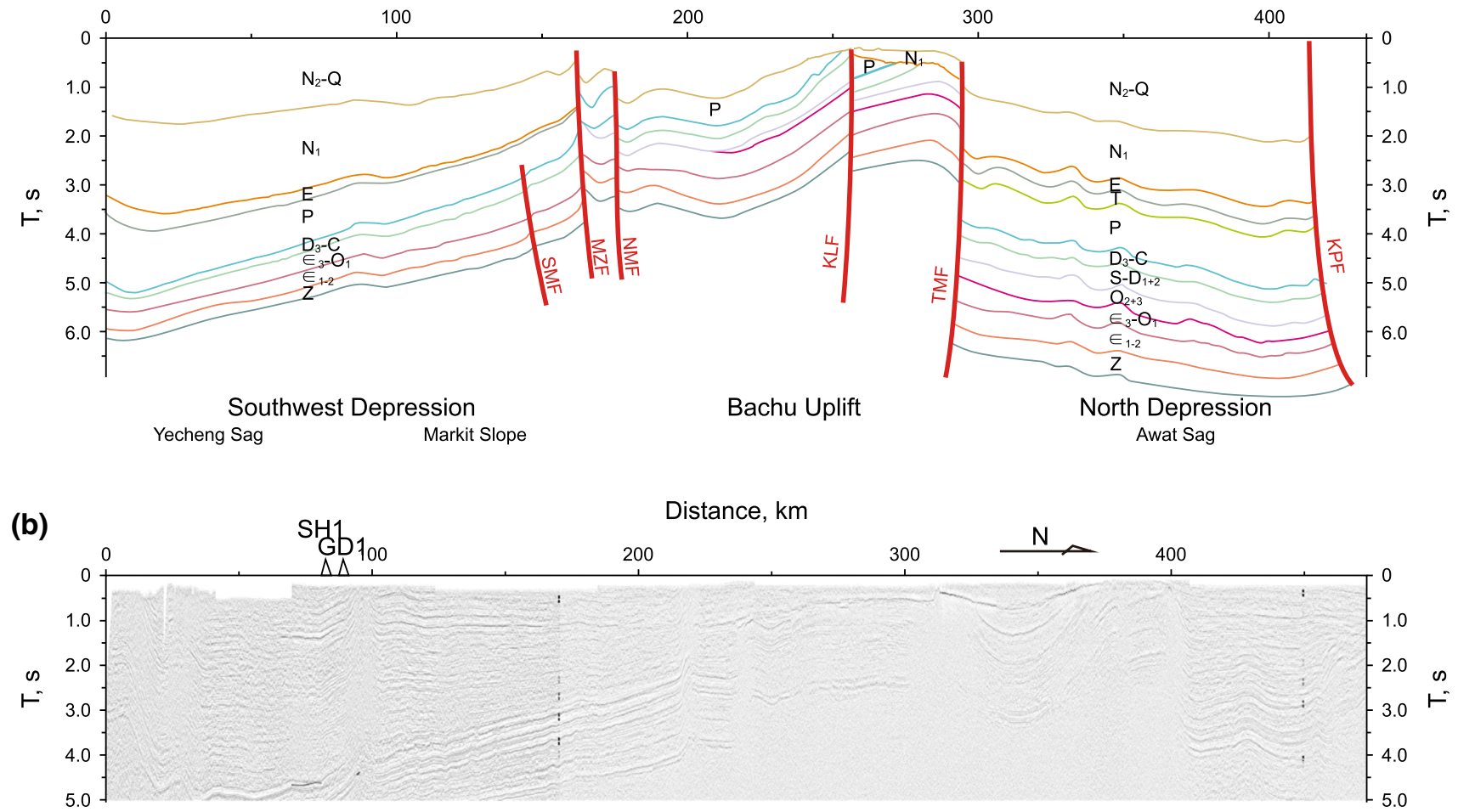

Distance, $\mathrm{km}$

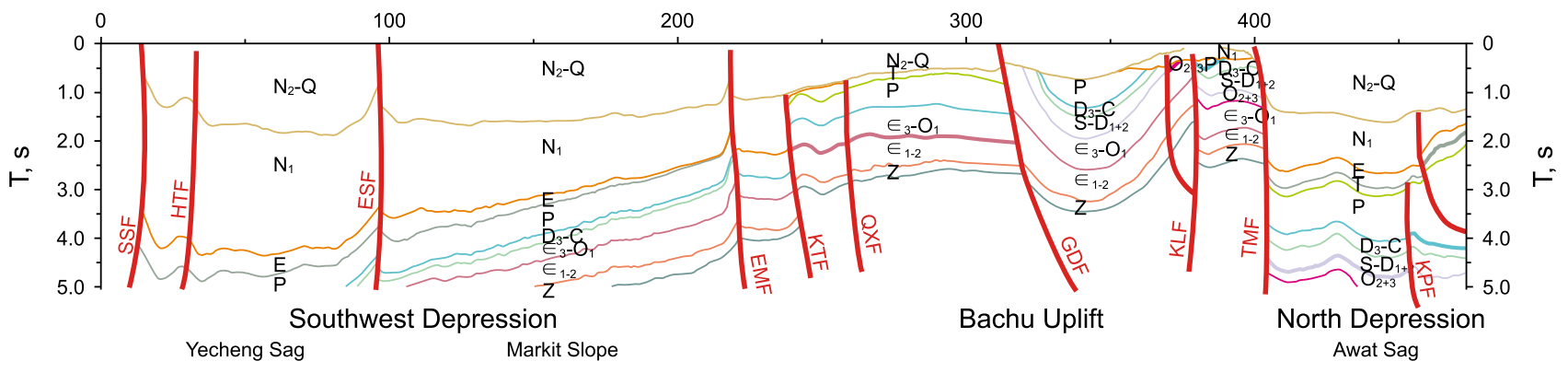

Fig. 5 Seismic profiles and geological interpretation of the TLM-Z15 (B-B', a) and TLM-Z10 (C-C', b) profiles. (The profile locations are shown in Fig. 2.) $\mathrm{SMF}=$ South Mazhatage Fault; MZF=Mazhatage Fault; NMF= North Mazhatage Fault; KLF=Kalashayi Fault; $\mathrm{TMF}=$ Tumuxiuke Fault; KPF $=$ Keping Fault; SSF $=$ South Sailajiasi Fault; HTF $=$ Hetian Fault; ESF $=$ East Shache Fault; EMF $=$ East Markit Fault; KTF= Katakumu Fault; QXF= Qiaoxiaoergai Fault; and GDF= Gudongshan Fault 
Distance, $\mathrm{km}$

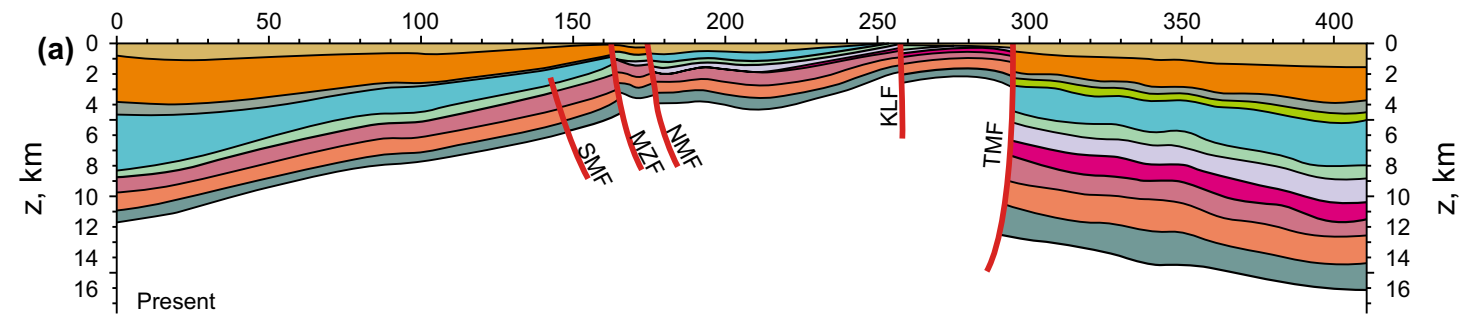

(b)

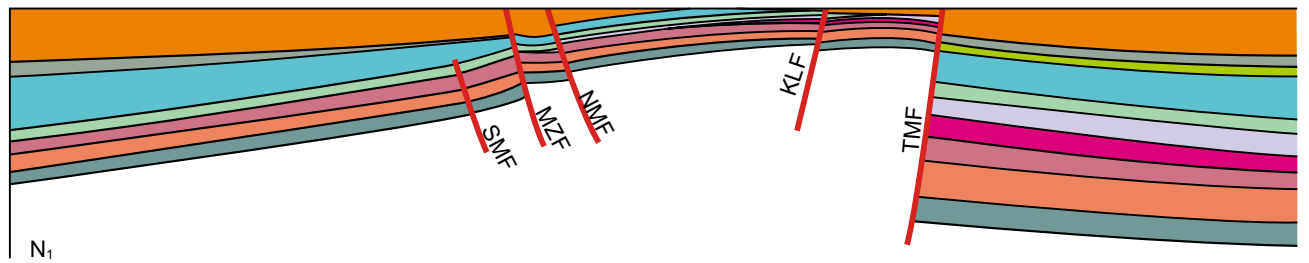

(c)

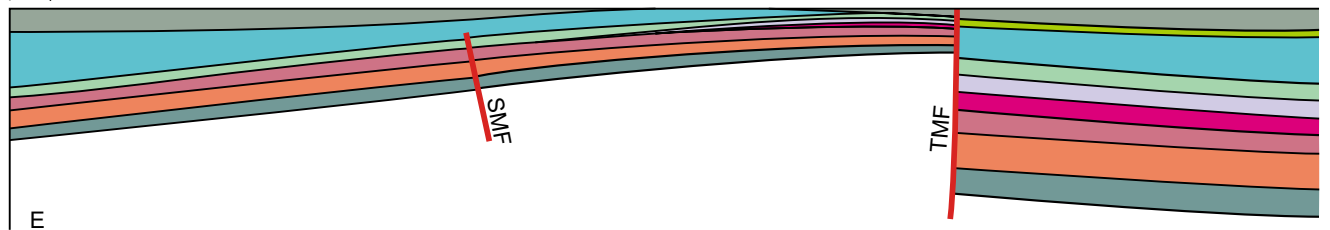

(d)

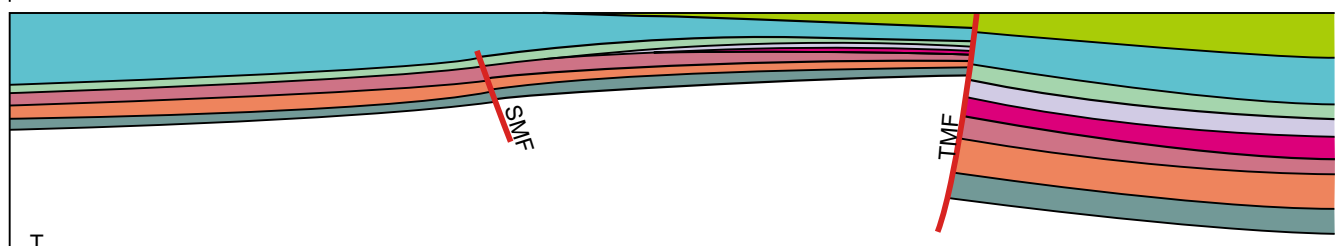

(e)

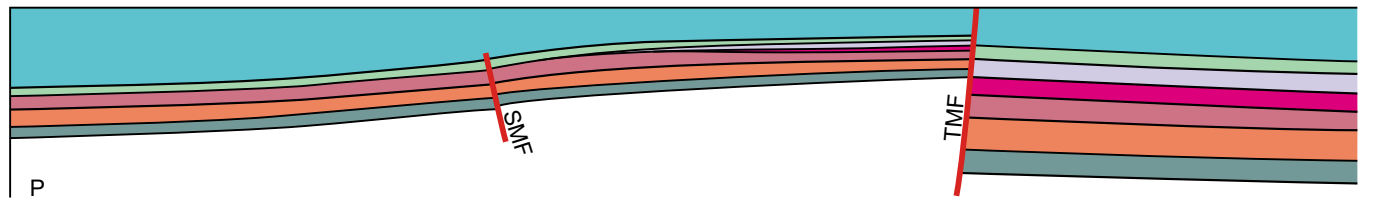

(f)

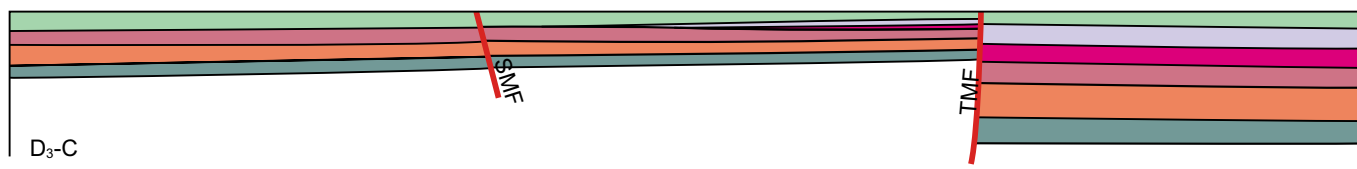

(g)
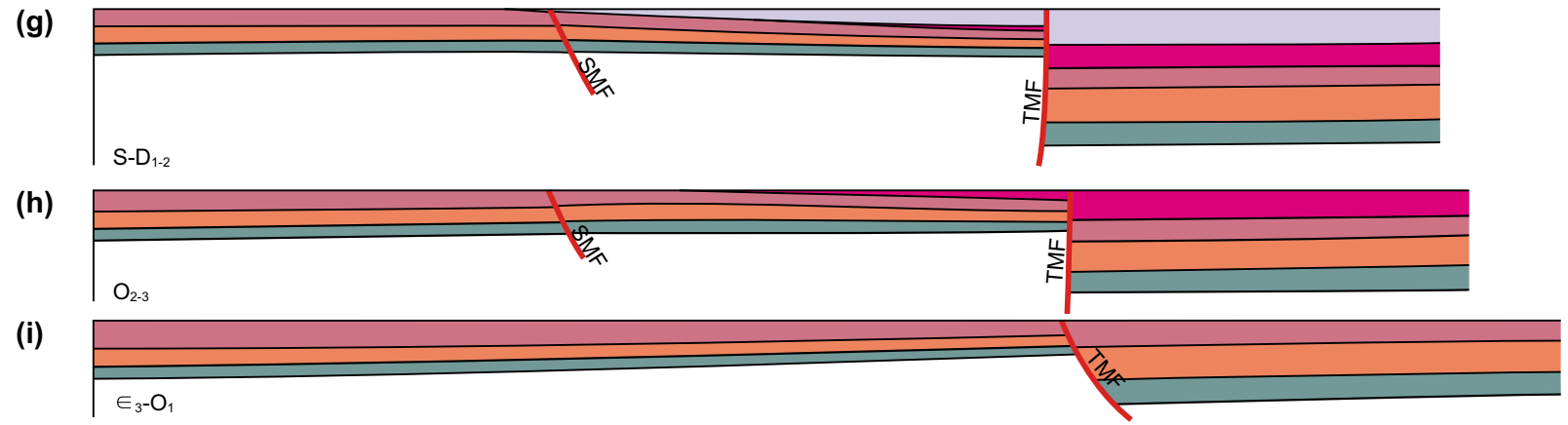

(j)

(k)

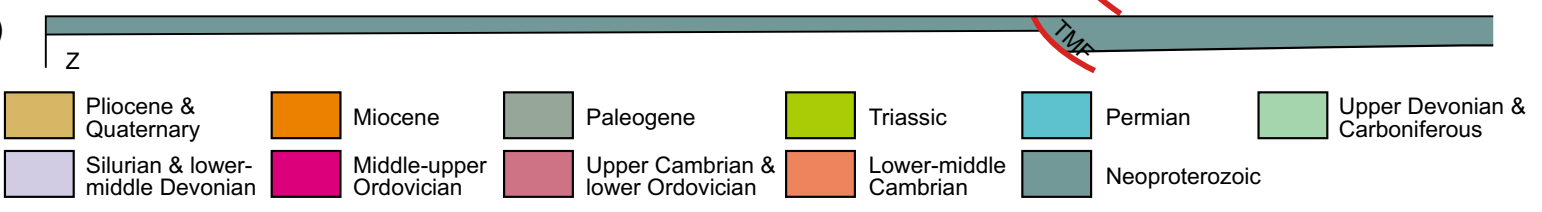

Fig. 6 Tectonic evolution of the TLM-Z15 (B-B') seismic profile 
Table 1 Tectonic evolution data from the TLM-Z15 (B-B') seismic profile

\begin{tabular}{|c|c|c|c|}
\hline Geological ages & $\begin{array}{l}\text { Length of } \\
\text { profile, } \mathrm{km}\end{array}$ & $\begin{array}{l}\text { Extensional } \\
\text { length, km }\end{array}$ & $\begin{array}{l}\text { Exten- } \\
\text { sional } \\
\text { ratio, } \\
\%\end{array}$ \\
\hline Neoproterozoic & 475 & & \\
\hline Early-Middle Cambrian & 483 & 8.0 & 1.68 \\
\hline $\begin{array}{l}\text { Late Cambrian and Early } \\
\text { Ordovician }\end{array}$ & 494 & 11.0 & 2.28 \\
\hline Early-Middle Ordovician & 463 & -31.0 & -6.28 \\
\hline $\begin{array}{l}\text { Silurian and Early-Middle } \\
\text { Devonian }\end{array}$ & 453 & -10.0 & -2.16 \\
\hline $\begin{array}{l}\text { Late Devonian and Carbonifer- } \\
\text { ous }\end{array}$ & 443.5 & -9.5 & -2.10 \\
\hline Permian & 441 & -2.5 & -0.56 \\
\hline Triassic & 435.5 & -5.5 & -1.25 \\
\hline \multicolumn{4}{|l|}{ Jurassic and Cretaceous } \\
\hline Paleogene & 430 & -5.5 & -1.26 \\
\hline Miocene & 423 & -7.0 & -1.63 \\
\hline Pliocene and Quaternary & 411 & -12.0 & -2.84 \\
\hline
\end{tabular}

- shortening

The tectonic evolution of TLM-Z10 (Fig. 7) is similar to that of TLM-Z15; thus, the detailed description will not be repeated. The structural style is slightly different in the Neogene and Quaternary in the northern part of the profile (Fig. 7a); i.e., the Keping Fault consists of deformation through multiple detachments, with upper and lower reverse faults.

The extensional ratio reflects the length changes in the TLM-Z10 profile (Table 2). Generally, the extensional ratio in each period for TLM-Z10 is numerically larger than that for TLM-Z15 because TLM-Z10 is closer to the edge of the basin and experienced stronger tectonic stress.

\section{Discussion}

\subsection{Basin prototypes}

\subsubsection{Structural styles}

Specific structural styles occur in different tectonic basins, reflecting different tectonic stress fields and basin properties. The structural styles that occurred in the balanced cross sections are summarized below.

A listric fault was developed during the Neoproterozoic to Early Ordovician. During the Middle Ordovician to
Carboniferous, a positive inverse fault was developed, i.e., a normal fault that becomes a reverse fault. After the Permian, pop-up structures, thrust faults and large synclines were developed.

\subsubsection{Basin prototypes}

The Tarim Basin has undergone a complicated tectonic evolution. From the Neoproterozoic to Early Ordovician, the western Tarim Basin was a rift basin during each period, i.e., the Neoproterozoic, Early-Middle Cambrian and Late Cambrian. From the Middle-Late Ordovician to the Early-Middle Devonian, the basin consisted of a flexural depression in the south and a depression that underwent a switch from a rifting depression to a flexural depression in the north during each period, i.e., the Middle and Late Ordovician and the Silurian to Middle Devonian. During the Late Devonian to Permian, the basin was a downwarped basin early and changed to a flexural basin late in each period, i.e., the Late Devonian to Carboniferous and Permian. In the Triassic, the basin was a foreland basin. During the Jurassic to Cretaceous, the basin was a downwarped basin. After the Paleogene, it became a rejuvenated foreland basin.

\subsection{The main stages in the evolution of the western Tarim Basin}

The evolutionary history is divided into three cycles (Fig. 8).

During the Neoproterozoic to Carboniferous, the Tarim Plate was an independent drifting plate. The surrounding terranes were far apart in the early stage (Duan et al. 2005). An extensional environment dominated, and the Tarim Basin was a rift basin. After the Middle Ordovician, collisions among the surrounding terranes occurred (Ren et al. 2017). Moreover, foreland basin structural styles appeared in the Tarim Basin. This stage ended with the collision between the Tarim Block and the Yili-Central Tianshan Terrane (Charvet et al. 2011; Liu et al. 2014; Ma et al. 2014).

During the Permian to Triassic, the Tarim Plate became the south margin of the Eurasian Plate. A compressional environment dominated in this stage, and the Tarim Basin was generally characterized by compressional structural styles. At the end of this stage, the Tarim Plate amalgamated with the Qiangtang Block (Mcquarrie et al. 2003; Wei et al. 2013).

Since the Jurassic, the Tarim Plate has been located within the Eurasian Plate. Extreme regional compression 


\section{Distance, $\mathrm{km}$}

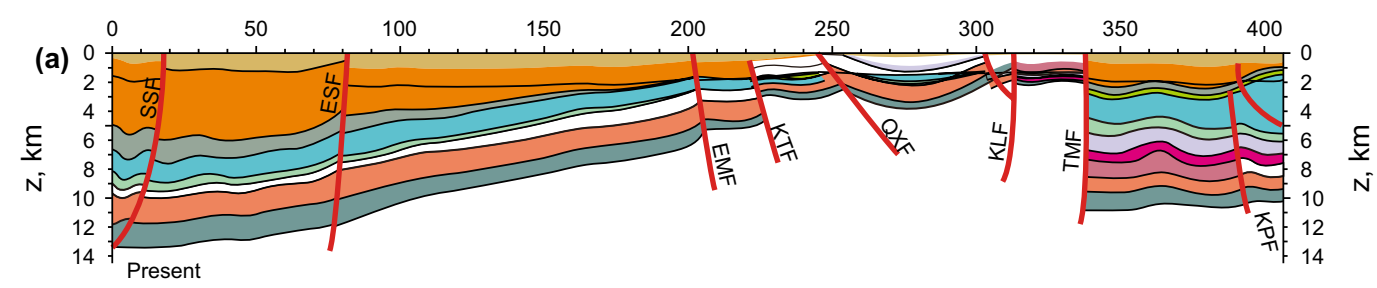

(b)

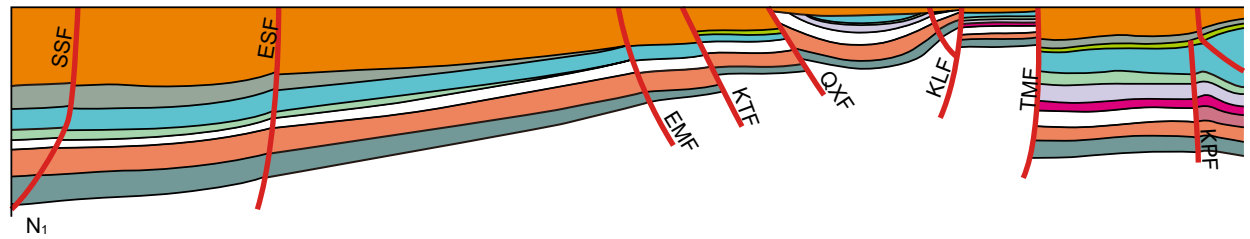

(c)

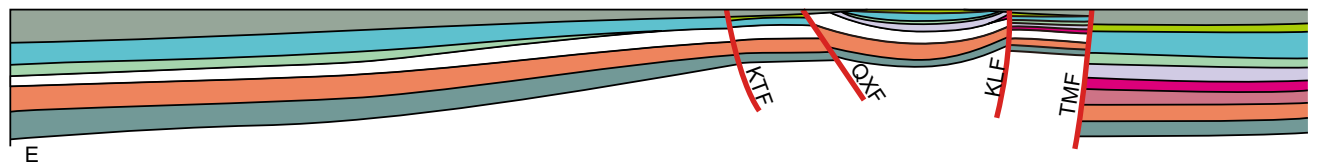

(d)

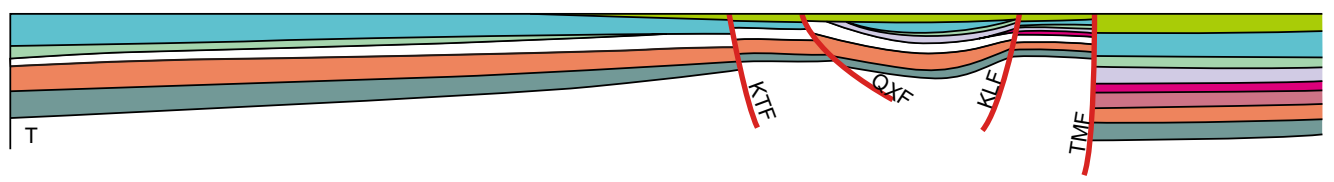

(e)

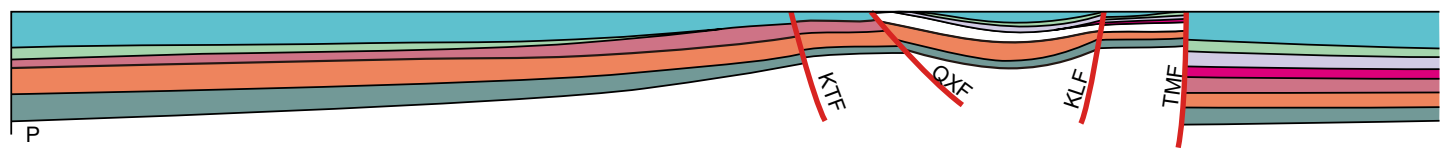

(f)

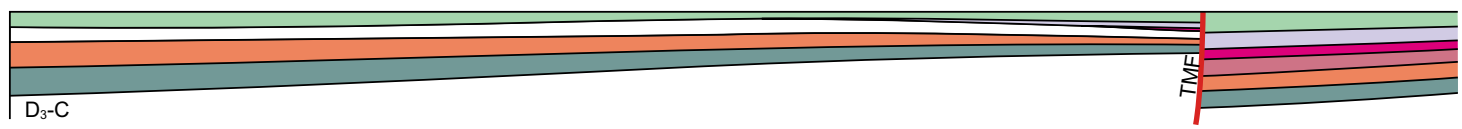

(g)

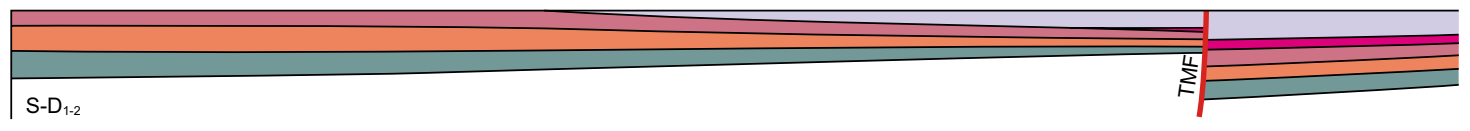

(h)

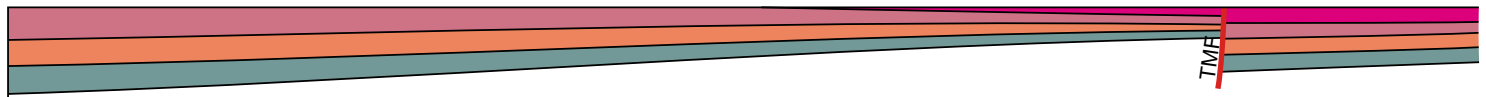

(i)

$$
\mathrm{O}_{2-3}
$$

(j)

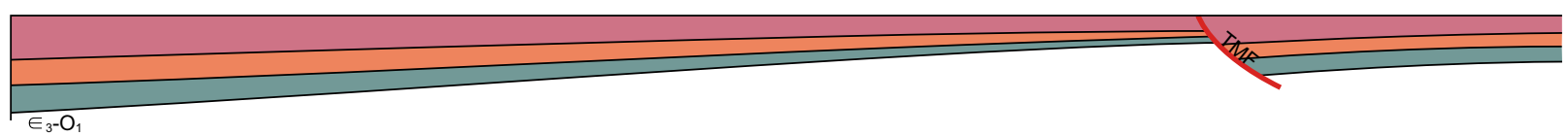

(k)
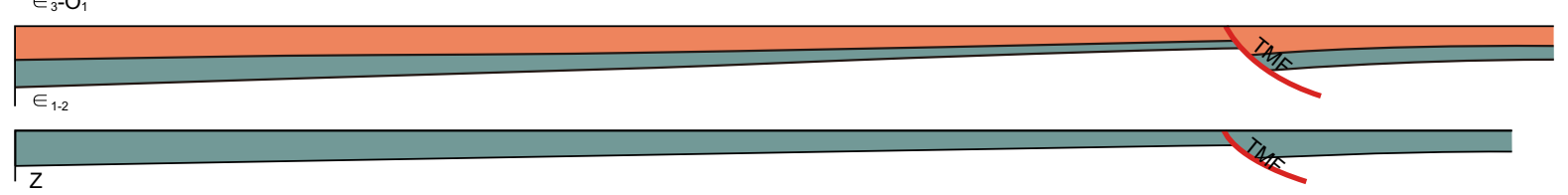

Fig. 7 Tectonic evolution of the TLM-Z10 $\left(\mathrm{C}-\mathrm{C}^{\prime}\right)$ seismic profile

resulted in the absence of Jurassic and Cretaceous strata. After the Paleogene, the Tarim Basin has acted as a rejuvenated foreland basin. Former structures are reactivated, and foreland basin-like subbasins appear in the basin, e.g., the Southwest Depression (Jiang et al. 2017). 
Table 2 Tectonic evolution data from the TLM-Z10 (C- $\left.\mathrm{C}^{\prime}\right)$ seismic profile

\begin{tabular}{llcc}
\hline Geological ages & $\begin{array}{l}\text { Length of } \\
\text { profile, } \mathrm{km}\end{array}$ & $\begin{array}{l}\text { Extensional } \\
\text { length, km }\end{array}$ & $\begin{array}{l}\text { Exten- } \\
\text { sional } \\
\text { ratio, } \\
\%\end{array}$ \\
\hline Neoproterozoic & 477 & & \\
Early-Middle Cambrian & 490 & 13.0 & 2.73 \\
Late Cambrian and Early & 505 & 15.0 & 3.06 \\
$\quad$ Ordovician & & & \\
Early-Middle Ordovician & 473 & -32.0 & -6.34 \\
Silurian and Early-Middle & 464 & -9.0 & -1.90 \\
$\quad \begin{array}{l}\text { Devonian } \\
\text { Late Devonian and Carbonifer- } \\
\quad \text { ous }\end{array}$ & 459 & -5.0 & -1.08 \\
$\begin{array}{l}\text { Permian } \\
\text { Triassic }\end{array}$ & 457 & -2.0 & -0.44 \\
Jurassic and Cretaceous & 455 & -2.0 & -0.44 \\
Paleogene & & & \\
Miocene & 453 & -2.0 & -0.44 \\
Pliocene and Quaternary & 431 & -22.0 & -4.86 \\
\hline
\end{tabular}

- shortening

\subsection{Causes for a composite and superimposed sedimentary basin}

The western Tarim Basin is a composite and superimposed sedimentary basin (Jia 2003). It is a superimposed basin because of its polycyclic multistage tectonic evolution, i.e., the temporal superimposition of different basin prototypes.
It is a composite basin because of the different basin properties in different parts of the basin, i.e., spatially variable basin prototypes.

A long-term and complicated tectonic evolution under the control of a long-term and changing regional stress field has made the western Tarim Basin a superimposed basin.

Because of its relatively large size and highly rigid and stable basement, the western Tarim Basin contains subbasins with different characteristics, e.g., in the Middle and Late Ordovician, the southwest subbasin was a flexural basin (a compressional basin), while the north subbasin was initially a rift basin (an extensional basin).

\section{Conclusions}

A long-term and complicated tectonic evolution and a highly rigid and stable basement have shaped the western Tarim Basin into a composite and superimposed sedimentary basin.

From the Neoproterozoic to Early Ordovician, the western Tarim Basin was a rift basin. From the Middle Ordovician to Middle Devonian, the basin consisted of a flexural depression in the south and a depression that switched from a rift depression to a flexural depression in the north. During the Late Devonian to Permian, the basin was first a downwarped basin and later changed to a flexural basin. In the Triassic, the basin was a foreland basin, and from the Jurassic to Cretaceous, it was a downwarped basin. After the Paleogene, the western Tarim Basin became a rejuvenated foreland basin.
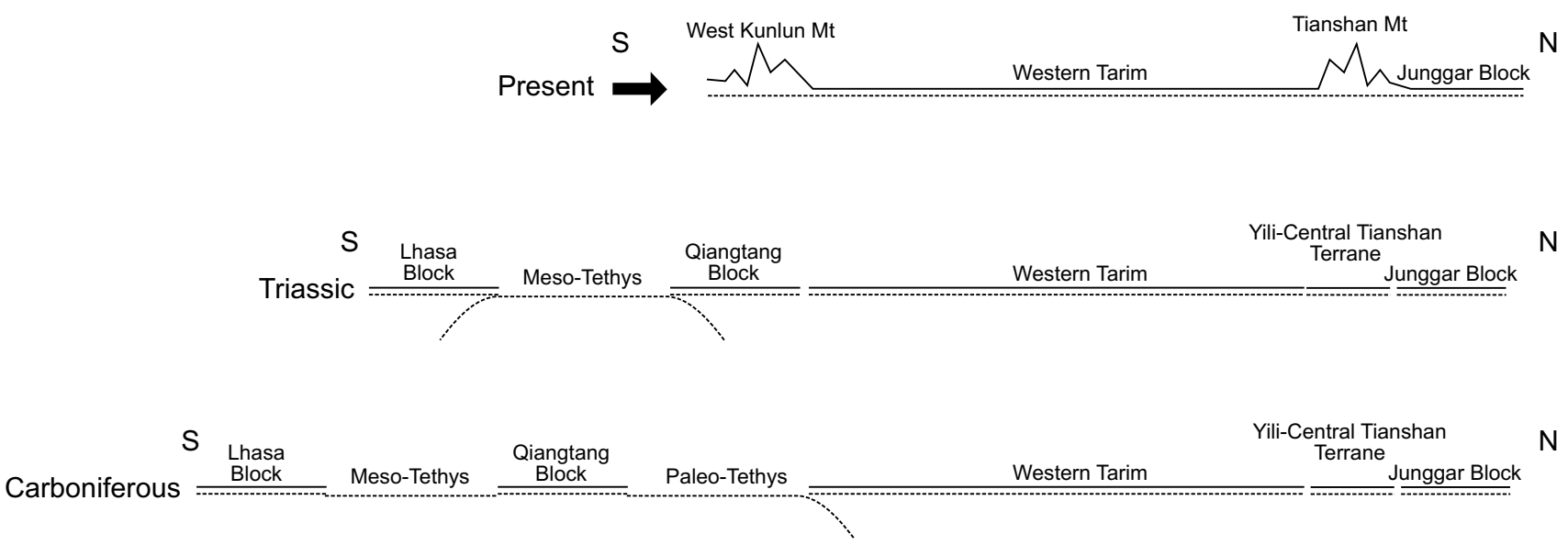

Fig. 8 Milestones that ended each cycle of the tectonic evolution of the western Tarim Basin 
Acknowledgements This work was supported by the China Postdoctoral Science Foundation (No. 2019M650960) and the Petro-China Tarim Oilfield Company (No. 041011080018).

Open Access This article is licensed under a Creative Commons Attribution 4.0 International License, which permits use, sharing, adaptation, distribution and reproduction in any medium or format, as long as you give appropriate credit to the original author(s) and the source, provide a link to the Creative Commons licence, and indicate if changes were made. The images or other third party material in this article are included in the article's Creative Commons licence, unless indicated otherwise in a credit line to the material. If material is not included in the article's Creative Commons licence and your intended use is not permitted by statutory regulation or exceeds the permitted use, you will need to obtain permission directly from the copyright holder. To view a copy of this licence, visit http://creativecommons.org/licenses/by/4.0/.

\section{References}

Charvet J, Shu LS, Laurent-Charvet S, et al. Palaeozoic tectonic evolution of the Tianshan belt, NW China. Sci China Earth Sci. 2011;54(2):166-84. https://doi.org/10.1007/s11430-010-4138-1.

Cutler RT, Bishop TN, Wyld HW, et al. Seismic tomography: formulation and methodology. SEG Tech Program Expand Abstr. 1984;50(2):856. https://doi.org/10.1190/1.1894311.

Duan J, Xia D, An S. Deep-water sedimentation and sedimentotectonopal eogeography of the Neoproterozoic-Early Palaeozoic aulacogen in Kuruktag, Xinjiang, China. Acta Geol Sin. 2005;79(1):7-14 (in Chinese).

Gao J, Long LL, Klemd R, et al. Tectonic evolution of the South Tianshan orogen and adjacent regions, NW China: geochemical and age constraints of granitoid rocks. Int J Earth Sci. 2009;98(6):1221-38. https://doi.org/10.1007/s00531-008-0370-8.

Ge R, Zhu W, Wu H, et al. The Paleozoic northern margin of the Tarim Craton: passive or active? Lithos. 2012;142-143(6):1-15. https:// doi.org/10.1016/j.lithos.2012.02.010.

Guo ZJ, Yin A, Robinson A, et al. Geochronology and geochemistry of deep-drill-core samples from the basement of the central Tarim Basin. J Asian Earth Sci. 2005;25(1):45-56. https://doi. org/10.1016/j.jseaes.2004.01.016.

He DF, Zhou XY, Zhang CJ, et al. Tectonic types and evolution of Ordovician proto-type basins in the Tarim region. Sci Bull. 2007;52(1):164-77. https://doi.org/10.1007/s11434-007-6010-z.

He Z, Gao S, Zheng M. Regional tectonic framework and evolution of superimposed basins in northwestern China. Earth Sci Front. 2015;22(3):227-40. https://doi.org/10.13745/j.esf.2015.03.020 (in Chinese).

Heermance RV, Chen J, Burbank DW, et al. Chronology and tectonic controls of Late Tertiary deposition in the southwestern Tian Shan foreland, NW China. Basin Res. 2007;19(4):599-632. https://doi. org/10.1111/j.1365-2117.2007.00339.x.

Ji S, Wang Q, Sun S, et al. Continental extrusion and seismicity in China. Acta Geol Sin. 2008;82(12):1644-67 (in Chinese).

Jia C. Plate tectoincs and continental dynamics of the Tarim plate. Beijing: Petroleum Industry Press; 2003 (in Chinese).

Jia C, Zhang S, Wu S. Stratigraphy of the Tarim Basin and adjacent areas. Beijing: Science Press; 2004 (in Chinese).

Jiang Z, Jiang S, Lan X, et al. Neotectonic evolution of the Tarim Basin Craton from Neogene to Quaternary. Int Geol Rev. 2017. https:// doi.org/10.1080/00206814.2017.1379365.

Jin X, Wang J, Chen B, et al. Cenozoic depositional sequences in the piedmont of the west Kunlun and their paleogeographic and tectonic implications. J Asian Earth Sci. 2003;21(7):755-65. https ://doi.org/10.1016/S1367-9120(02)00073-1.

Kao H, Gao R, Rau RJ, et al. Seismic image of the Tarim Basin and its collision with Tibet. Geology. 2001;29(7):575-8. https://doi. org/10.1130/0091-7613(2001)029\%3c0575:siottb\%3e2.0.co;2.

Li S, Zhao S, Liu X, et al. Closure of the Proto-Tethys Ocean and Early Paleozoic amalgamation of microcontinental blocks in East Asia. Earth Sci Rev. 2017. https://doi.org/10.1016/j.earsc irev.2017.01.011.

Li Y, Song W, Wu G, et al. Jinning granodiorite and diorite deeply concealed in the central Tarim Basin. Sci China, Ser D Earth Sci. 2005;48(12):2061-8. https://doi.org/10.1360/03yd0354.

Lin C, Li H, Liu J. Major unconformities, tectonostratigraphic frameword, and evolution of the superimposed Tarim Basin, Northwest China. J Earth Sci. 2012;23(4):395-407. https://doi.org/10.1007/ s12583-012-0263-4.

Liu DD, Guo ZJ, Jolivet M, et al. Petrology and geochemistry of Early Permian volcanic rocks in South Tian Shan, NW China: implications for the tectonic evolution and Phanerozoic continental growth. Int J Earth Sci. 2014;103(3):737-56. https://doi. org/10.1007/s00531-013-0994-1.

Liu WP, Wang H, Tong LX, et al. Geochemical characteristics and metamorphic P-T paths of the Bulunkuole Group in Taxkorgan, western Kunlun. Acta Petrol Sin. 2013;29(3):923-37 (in Chinese).

Liu X, Wang Y. A brief analysis of tectonic movements on the Tarim plate and its surrounding areas. Acta Geos Sin. 1995;16(3):24660 (in Chinese).

Lu H, Howell D, Jia D, et al. Rejuvenation of the Kuqa Foreland Basin, Northern Flank of the Tarim Basin, Northwest China. Int Geol Rev. 1994;36(12):1151-8. https://doi.org/10.1080/0020681940 9465509.

Ma XX, Shu LS, Meert JG, et al. The Paleozoic evolution of Central Tianshan: geochemical and geochronological evidence. Gondwana Res. 2014;25(2):797-819. https://doi.org/10.1016/j. gr.2013.05.015.

Mcquarrie N, Stock JM, Verdel C, et al. Cenozoic evolution of Neotethys and implications for the causes of plate motions. Geophys Res Lett. 2003;30(20):315-31.

Metcalfe I. Gondwana dispersion and Asian accretion: tectonic and palaeogeographic evolution of eastern Tethys. J Asian Earth Sci. 2013;66:1-33. https://doi.org/10.1016/j.jseaes.2012.12.020.

Molnar P, Tapponnier P. Relation of the tectonics of eastern China to the India-Eurasia collision: Application of slip-line field theory to large-scale continental tectonics. 1977;5(4):212-6. https://doi. org/10.1130/0091-7613(1977)5\%3c212:ROTTOE\%3e2.0.CO;2.

Pullen A, Kapp P, Gehrels GE, et al. Triassic continental subduction in central Tibet and Mediterranean-style closure of the Paleo-Tethys Ocean. Geology. 2015;36(5):351-4. https://doi.org/10.1130/ G24435A.1.

Qu G, Li Y, Li Y, et al. Segmentations of foreland belts and their tectonic mechanism in the Southwest Tarim Basin. Sci China Earth Sci. 2005;48(10):1585-98. https://doi.org/10.1360/02YD0071.

Ren R, Guan SW, Han BF, et al. Chronological constraints on the tectonic evolution of the Chinese Tianshan Orogen through detrital zircons from modern and palaeo-river sands. Int Geol Rev. 2017;59(13):1657-76. https://doi.org/10.1080/00206 814.2017.1292468.

Sobel ER, Dumitru TA. Thrusting and exhumation around the margins of the western Tarim basin during the India-Asia collision. J Geophys Res Solid Earth. 1997;102(B3):5043-63.

$\mathrm{Su}$ W, Gao J, Klemd R, et al. U-Pb zircon geochronology of Tianshan eclogites in NWChina: implication for the collision between the Yili and Tarim blocks of the southwestern Altaids. Eur J Mineral. 2010;22(4):473-8. https://doi. org/10.1127/0935-1221/2010/0022-2040. 
Tian Z, Chai G, Kang Y. Tectonic evolution of the Tarim basin. In: Zhu $\mathrm{X}$, editor. Chinese sedimentary basins, sedimentary basins of the world. Elsevier: Amsterdam; 1989. p. 33-42.

Tromp J, Tape C, Liu Q. Seismic tomography, adjoint methods, time reversal and banana-doughnut kernels. Geophys J R Astron Soc. 2010;160(1):195-216. https://doi.org/10.1111/j.1365246X.2004.02453.x.

Wang SL, Shu LS, Zhu WB, et al. Mesozoic faults in the NE Tarim (western China) and the implications on collisions in the southern Eurasian margin. J Asian Earth Sci. 2012;56:191-9. https://doi. org/10.1016/j.jseaes.2012.05.012.

Wei HH, Meng QR, Ding L, et al. Tertiary evolution of the western Tarim Basin, northwest China: a tectono-sedimentary response to northward indentation of the Pamir salient. Tectonics. 2013;32(3):558-75. https://doi.org/10.1002/tect.20046.

Xiao W, Han F, Windley B, et al. Multiple accretionary orogenesis and episodic growth of continents: insights from the Western Kunlun Range, central Asia. Int Geol Rev. 2003;45(4):303-28. https://doi. org/10.2747/0020-6814.45.4.303.

$\mathrm{Xu} \mathrm{Z}$, Dilek Y, Cao H, et al. Paleo-Tethyan evolution of Tibet as recorded in the East Cimmerides and West Cathaysides. J Asian Earth Sci. 2015;105:320-37. https://doi.org/10.1016/j.jseae s.2015.01.021.

Xu Z, Li S, Zhang J, et al. Paleo-Asian and Tethyan tectonic systems with docking the Tarim block. Acta Petrol Sin. 2011;27(1):1-22 (in Chinese).
Xu ZQ, He BZ, Zhang CL, et al. Tectonic framework and crustal evolution of the Precambrian basement of the Tarim Block in NW China: new geochronological evidence from deep drilling samples. Precambrian Res. 2013;235(235):150-62. https://doi. org/10.1016/j.precamres.2013.06.001.

Zhang B, Chen W, Yu S, et al. Subduction process of South Tianshan Ocean during Paleozoic. Acta Petrol Sin. 2014;30(8):2351-62 (in Chinese).

Zhang L, Long X, Zhang R, et al. Source characteristics and provenance of metasedimentary rocks from the Kangxiwa Group in the Western Kunlun Orogenic Belt, NW China: implications for tectonic setting and crustal growth. Gondwana Res. 2017a;46:43-56. https://doi.org/10.1016/j.gr.2017.02.014.

Zhang X, Zhao J, Zhang C, et al. Crustal structure at the northeast side of the Pamirs. Chin J Geophys. 2002;45(5):665-71 (in Chinese).

Zhang YX, Li ZW, Yang WG, et al. Late Jurassic-Early Cretaceous episodic development of the Bangong Meso-Tethyan subduction: evidence from elemental and $\mathrm{Sr}-\mathrm{Nd}$ isotopic geochemistry of arc magmatic rocks, Gaize region, central Tibet, China. J Asian Earth Sci. 2017b;135:212-42. https://doi.org/10.1016/j.jseae s.2016.12.043.

Zhao D. Multiscale seismic tomography and mantle dynamics. Gondwana Res. 2009;15(3-4):297-323. https://doi.org/10.1016/j. gr.2008.07.003. 